\title{
Unipolar hip prosthesis with nanocomposite ceramic coated femoral head
}

\author{
A. Zykova ${ }^{\text {1, V. Safonov }}{ }^{\text {, }}$ V. Lukyanchenko ${ }^{2}$, A. Samoilenko ${ }^{3}$, \\ R. Rogovska ${ }^{4}$, J. Smolik ${ }^{4}$, N. Donkov ${ }^{5}$ \\ ${ }^{1}$ National Science Centre «Kharkov Institute of Physics and Technology». Ukraine \\ ${ }^{2}$ Inmasters Ltd, Kharkov. Ukraine \\ ${ }^{3}$ Lugansk State Medical University. Ukraine \\ ${ }^{4}$ Institute of Teratechnology, Radom. Poland \\ ${ }^{5}$ Institute of Electronics BAS, Sofia. Bulgaria
}

Hip arthroplasty in elderly patients is the most progressive method of medical treatment. The method provides rapid recovery and rehabilitation of musculoskeletal systems at an earlier period. The aim of the present study was to analyze the structural and mechanical properties of unipolar prosthesis head surfaces made of titanium and stainless steel and coated by oxide and oxynitride nanocomposite for hemiarthroplastic hip replacement as well as clinical approbation of prostheses «BES-T Manufacturing» (Ukraine), for possibility of applying this technology in traumatology. The structure of $\mathrm{Al}_{2} \mathrm{O}_{3}(\mathrm{MS})$ and $\mathrm{AlN} / \mathrm{Al2O} \mathrm{O}_{3}(\mathrm{MS})$ magnetron sputtered films was investigated by means of XPS and XRD methods. The surface topography and roughness was estimated by profilometer Hommel T-2000 measurements and by AFM method. ElvaX spectrometer is modern analytical equipment for high-line non-destructive elemental analysis. The analysis of the results of treatment patient's with fractures of the femoral neck under observation period from 12 months to 3 years was presented. The unipolar hip replacement operations were made in urban trauma hospital during the period from 2012 to 2014. The age of patients was in the range from 72 to 86 years. All patients had a history of intra-articular fractures of the femoral neck. The joint femoral head surfaces with nanocomposite oxide and oxinitride coatings demonstrate improved biocompatibility due to wettability increasing and fluid friction characteristics advancing. The deep understanding of the tribology of artificial joints is essential for reducing wear and corrosion of modern prostheses. Deposition of ceramic coatings on a surface of metal artificial joint's head is an effective way to advance the functional characteristics of unipolar and bipolar prosthesis for joint arthroplasty.
Эндопротезирование тазобедренного сустава у пожильх паилентов - наиболее прогрессивный метод лечения переломов шейки бедренной кости. Метод обеспечивает быстрое восстановление и реабилитацию опорно-двигательной системы в более ранний период. Цель: проанализировать структурные и механические свойства головок однополюсных эндопротезов тазобедренного сустава из титана и нержавеющей стали с оксидными и оксинитридныли нанокомпозитными покрытиями, а также провести клиническую апробацию эндопротезов «BES-T Manufacturing» (Украина). Методы: нанооксидные покрытия головок однополюсных эндопротезов исследовали с помощью профилометра Ноттеl T-2000, выполняли коррозионные тесты. С помощью спектрометра ElvaX проанализировали скользящие поверхности титана и нержавеющей стали однополюсньх эндопротезов, удаленных при ревизионном эндопротезировании. В период с 2012 по 2014 г2. 14 пациенткам в возрасте 72-86 лет с переломами шейки бедренной кости выполнена гемиартропластика с помощью однополюсного эндопротеза фирмы «BES-T Manufacturing». Головка эндопротеза из нержавеющей стали конхоидной формы покрыта пленкой из наноструктурированного $\mathrm{Al}_{2} \mathrm{O}_{3}$. Операчии проведень в травматологических отделениях городских больниц. Результать:: головки эндопротезов с оксидными и оксинитридными нанокомпозитныли покрытиями обладают улучшенной биосовместимостью и увеличенной смачиваемостью поверхности. Применение достижений трибологии в искусственных суставах чрезвычайно важно для снижения износа и коррозии эндопротезов. Нанесение керамических покрытий на поверхности головок металлических искусственных суставов эффективно для совершенствования их функциональных характеристик. Данная техническая разработка может быть использована и в случае биполярного протезирования тазобедренного сустава. Ключевые слова: гемиартропластика, искусственные суставы, многослойные покрытия, трибология, смачиваемость. 
Key words: hemiarthroplasty, artificial joints, multilayer coatings, tribology, wettability

\section{Introduction}

The total replacement of hip-femoral joints is a successful, safe and cost-effective clinical treatment in modern medicine practice [1-3]. Femoral neck fractures are a common insufficiency fracture in the elderly. The ageing of population requires new advancing strategies of patient's treatment. The most common medical indication for surgery operation is advanced osteoarthritis, a degenerative joint disease, and loss of mobility functions. Other factors are various bone defects caused by accidents or diseases. At the process of the femoral head arthroplasty the most important is the evaluation of patient's anatomical features for enhancement of tribological parameters of modular joints. The principal advantage of modular prosthesis application is the possibility of revision operation in the case of significant migration of joint femoral head to pelvis. The long-term experience of different patience group's research demonstrates high survival parameters under medical observations above $20-30$ years [4-8].

Quality of life after hip arthroplasty and function of artificial joints are much better than using the osteosynthesis [9-11]. Taking into account, that in such case the degree of surgical intervention using unipolar and bipolar prosthesis lower, and the majority of elderly patients have concurrent somatic diseases, hemiarthroplasty remains the method of choice for fractures of the femoral neck [12-16]. In modern clinical practice, mainly Austin-Moore and Thompson joints, with no significant design changes in the shape and material of the prosthesis head, which should protect against damage to the cartilage of the acetabulum are applied. The prosthesis heads used in joint replacement made the mechanical functions only, have not the specific biophysical properties. These prosthesis types are not adapted to work in tandem with articular cartilage as antifriction microporous elastic tissue, the pores of which are filled with synovial fluid that performs the function of «lubrication» of the joint.

Under the loading conditions, the joint synovial fluid is squeezed out of the pores in the areas of greatest contact stress, degeneration of cartilage and subchondral bone. Therefore, the absence of a biological system of endoprostheses lubrication causes fatigue mechanism of wear and, as a result, the migration of the prosthesis head. Also often patients disturb a pain in the post operation period after unipolar prosthetics. Patient's quality of life significantly reduces because of chronic pain syndrome. One of the immediate causes of pain may be a nidus of inflammation formed by the accumulation of wear debris surrounding the implant tissues, especially in the case of titanium. The most important complication, which limits the lifetime of prosthesis, is aseptic loosening due to an inflammatory reaction against wear debris that can occur even many years after surgery. Adverse tissue reactions, such as the formation of pseudotumours, are frequent complications after operations [11-13]. Also, the clinical cases of metallosis after using the unipolar prostheses, when the accumulation of wear debris leads to pain, inflammation, bone resorption have been reported. The average period of the clinical complications and the migration of the femoral head may be 5-8 years after prosthesis, but there are reports of revision surgery after 10-13 years after hemiarthroplasty [16]. Problems with friction in the case of total arthroplasty also were reported [17-19]. One solution to this problem has been to increase the mechanical and hydrophilic properties of the prosthesis head surface by means of different coating deposition methods [20-22].

The continuous intense efforts are focused to develop novel prosthesis designs and materials with tailored properties in order to increase lifetime and to reduce the necessity of revision treatment. Wear is defined as the most important limitation to long-term stability of artificial joints. The presence of a lubricant film or coatings in the contact region may minimize surface damage and material losses. Significant interest is focused to tribological performance of modern prosthesis. The application of metal materials with ceramic coatings is the effective way of alternative bearing surfaces formation. The ceramic aluminum oxide and oxynitride coatings (fig. 1) are widely used as protective coatings against wear, diffusion and corrosion [23-25]. The enhancement of mechanical properties such as hardness parameters, effective Young's modulus, and toughness of the coatings is very important for tribological performance of the next generation of ceramic-coated femoral heads of unipolar prosthesis and total joints.

The aim of the present study was to analyze the structural and mechanical properties of unipolar prosthesis head surfaces made of titanium and stainless steel and coated by oxide and oxynitride nanocomposite for hemiarthroplastic hip replacement as well as clinical approbation of prostheses «BES-T Manufacturing» (Ukraine), for possibility of applying this technology in traumatology.

\section{Material and methods}

The substrates for deposited coatings were the popular implant materials such as the stainless steel (1H18N9) and titanium-based material (Ti4Al6V). The 

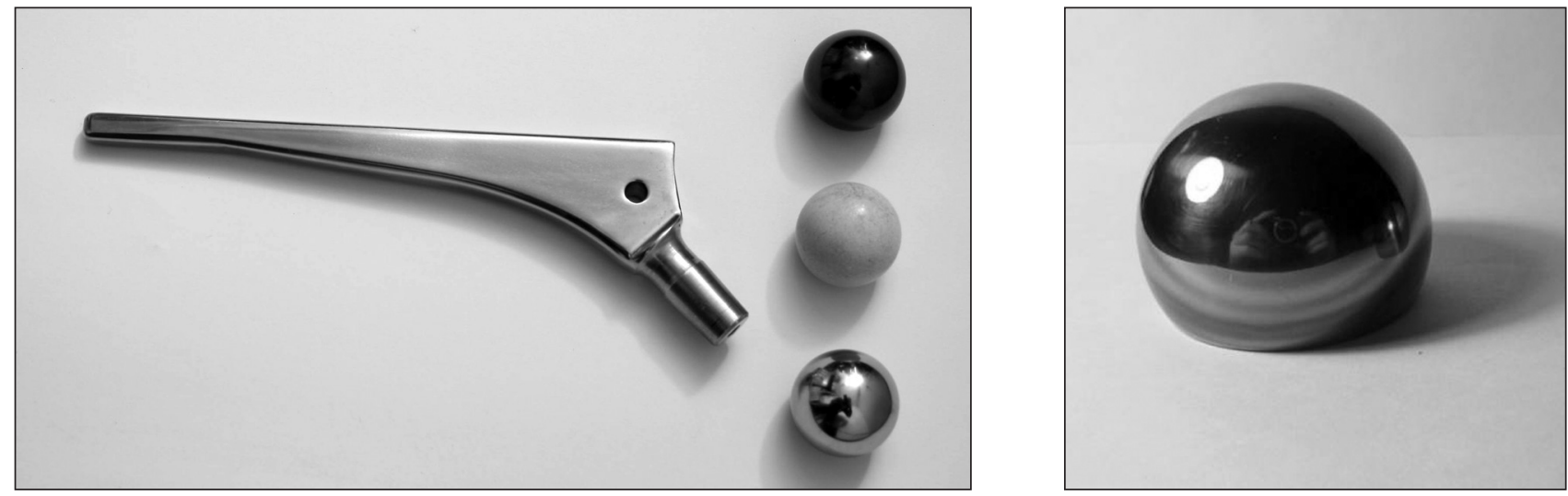

Fig. 1. Unipolar femoral head surfaces made of stainless steel coated by oxide and oxynitride nanocomposite films

substrates were cleaned in ultrasonic bath with standard technology. The nano structural $\mathrm{Al}_{2} \mathrm{O}_{3}(\mathrm{MS})$ and $\mathrm{AlN} / \mathrm{Al}_{2} \mathrm{O}_{3}$ (MS) films were deposited by magnetron sputtering method in high vacuum pumping system. The main details of the magnetron and ion source in the sputtering chamber were demonstrated at [21-25].

The structure of $\mathrm{Al}_{2} \mathrm{O}_{3}(\mathrm{MS})$ and $\mathrm{AlN} / \mathrm{Al}_{2} \mathrm{O}_{3}(\mathrm{MS})$ magnetron sputtered films was investigated by means of XPS and XRD methods. X-ray diffraction profiles of $\mathrm{Al}_{2} \mathrm{O}_{3}$ (MS) were observed by means of diffraction device «DRON-3» with filtered $\mathrm{Cu}-\mathrm{Ku}$ radiation. $\mathrm{X}$-ray photoelectron spectroscopy was carried out using ESCALAB MkII (VG Scientific) electron spectrometer, using AlKalpha X-ray source (excitation energy $\mathrm{h} v=1486.6 \mathrm{eV})$. The instrumental resolution measured as the full width at a half maximum (FWHM) of the $\mathrm{Ag} 3 \mathrm{~d} 5 / 2$, photoelectron peak is $1 \mathrm{eV}$. The coatings thickness, hardness and elastic modulus, were evaluated by standard methods [24].The adhesion parameters and friction coefficients were measured by Scratch method within the load range of 0-200 N. The surface topography and roughness was estimated by profilometer Hommel T-2000 measurements and by AFM method. The abrasive wear of different coatings on metal substrates were investigated according to $[26,27]$ and reported previously [23-25].

The corrosion tests by potentiodynamic method, Tafel and Stern curves were made by Potentiostat PARSTAT 2263 (AMETEK, USA). The corrosion examinations of anodic polarization at the potential range $-1.0 \mathrm{~V}-+2.0 \mathrm{~V}$ with scanning rate $1 \mathrm{mv} / \mathrm{s}$, Tafel $-0.050 \mathrm{~V}-+0.050 \mathrm{~V}$ and Stern $-0.020 \mathrm{~V}-+0.020 \mathrm{~V}$ range curves at $0.5 \mathrm{~N} \mathrm{NaCl}$ and $\mathrm{SBF}(\mathrm{NaCl}-8,035$, $\mathrm{NaHCO}_{3}-0,355, \mathrm{KCl}-0,225, \mathrm{~K}_{2} \mathrm{HPO}_{4} 3 \mathrm{H}_{2} \mathrm{O}-0,231$, $\left.\mathrm{MgCl}_{2} 6 \mathrm{H}_{2} \mathrm{O}-0,311, \mathrm{CaCl}_{2}-0,292, \mathrm{Na}_{2} \mathrm{SO}_{4}-0,072\right)$ at $\mathrm{pH}=7.4$ and temperature $37^{\circ} \mathrm{C}$ solu-tions were recorded. Advancing contact angles were measured by Wilhelm's method (Kruss K12) at temperature $20{ }^{\circ} \mathrm{C}[21]$.
ElvaX spectrometer is modern analytical equipment for high-line non-destructive elemental analysis. The device is designed for rapid qualitative and quantitative analysis of materials from the contents of the chemical elements $\mathrm{Mg}$ (atomic number $Z=12)$ to $U(Z=92)$ over a wide range of concentrations. Accuracy of determining concentrations of metals in alloys $0,1-0,3 \%$. Limits of detection of metal impurities are of the order of $10 \mathrm{ppm}$.

The analysis of the results of treatment of 12 patients with fractures of the femoral neck under observation period from 12 months to 3 years was presented. The unipolar hip replacement operations were made in urban trauma hospital during the period from 2010 to 2014 for 10 women and 2 men. The age of patients was in the range from 69 to 83 years. All patients had a history of intra-articular fractures of the femoral neck. In our clinical observations used the following unipolar prostheses: titanium prosthesis of «Inmed» (Kiev, Ukraine) - 1 piece, prosthesis company «Motor Sich» (Zaporozhye, Ukraine) - 3 pieces, prosthesis of «ORTEN» (Dnepropetrovsk, Ukraine) - 2 pieces, stainless steel prosthesis by company «Narang» (India) -6 pieces. An elemental com-position of the surface of the head of the prosthesis in the most exposed areas was stud-ied by the spectrometer ElvaX. The upper pole of the head of the prosthesis (exposed surfaces), the lower pole of the prosthesis head (not exposed surfaces), the surface of the cement mantle near the neck of the prosthesis, the surface of the bone near the neck of the prosthesis were observed.

For 14 patients, women 72-86 years, unipolar prosthesis of stainless steel («BES-T Manufacturing», Ukraine) were implanted in 2012-2014 years. The heads of the fem-oral prosthesis «BES-T Manufacturing» were coated by oxide and oxynitride nanocomposite ceramic films. Patients were examined clinically. Radiographs of the hip were performed in direct projection at 3, 6, 12, 24, 30 months. The clinical observation of pa-tients was recorded. 


\section{Results and discussion}

The structure of oxide and composite magnetron sputtering (MS) thin films was investigated by means of XPS and XRD methods. X-ray diffraction profiles of MS de-posited coatings .demonstrate a lower crystallinity. The structural analysis of coatings by means of XPS method also was made $[20,24]$. The photoelectron spectra of A12p, O1s, N1s and C1s were observed and confirmed strong compound stoichiometric composition. The surface structure and morphology was investigated by means of AFM and SEM methods. The surface of oxide $\mathrm{Al}_{2} \mathrm{O}_{3}$ (MS) coatings has smooth relief with uniform cross-section structure. The AlN coatings have crystalline structure with crystalline phase fracture section.

The coatings thickness was $2.1 \mu \mathrm{m}$ for stainless steel and $1.8 \mu \mathrm{m}$ in the case of ti-tanium alloy substrates. The roughness parameters $R_{a} / R_{z}$ of the uncoated and oxide coated stainless steel substrates were $0.007 / 0.040 \mu \mathrm{m}$ and $037 / 0.240 \mu \mathrm{m}$, corresponding-ly. In the case of titanium alloy substrates the roughness parameters have a values $R_{a} / R_{z} 0.013 / 0.187 \mu \mathrm{m}$ and $0.117 / 0.797 \mu \mathrm{m}$. The friction coefficient of oxide coatings on the stainless substrate was about 0.1 and was less than for metal materials with a strong tendency to decrease in fluids up to value 0.07 . Reduction of the friction coefficient can be attributed to adsorbed liquids providing the lubrication or to ceramics tribochemical reactions with formation of hydrated surface layers acting as solid lubricant films. The mechanical properties of the coatings are the hardness $\mathrm{H}$ and effective Young's modulus E*. Mechanical behavior of the films is characterized by the ratio $\mathrm{H} / \mathrm{E}^{*}[22,23]$. There is the correlation between the mechanical properties and coating structure. The incorporation of the nano crystalline phase transition layer of composite coating in the amorphous matrix strongly increases the values of $\mathrm{H}, \mathrm{H} / \mathrm{E}^{*}$ and mechanical properties of nitride/oxide composite films.

The mechanical parameters of composite oxide and oxynitride coatings deposited on the SS and Ti alloy substrates were presented in the table 1 .

The addition of nitride layer in the composite coating's structure strongly increases the hardness of films from 9 to $14 \mathrm{Gpa}$ and the ratio $\mathrm{H} / \mathrm{E}^{*}$ from 0.05 to 0.08 . The en-hancement of mechanical properties
Table 1

Mechanical characteristics of oxide and oxynitride coatings deposited on the stainless steel (1H18N9) and titanium alloy substrates (Ti4Al6V)

\begin{tabular}{|l|c|c|c|c|}
\hline \multirow{2}{*}{$\begin{array}{c}\text { Material/ } \\
\text { Coating type }\end{array}$} & \multicolumn{4}{|c|}{ Mechanical parameters (average results 10 tests) } \\
\cline { 2 - 5 } & $\begin{array}{c}\text { Hardness } \mathrm{H} \\
{[\mathrm{GPa}]}\end{array}$ & $\begin{array}{c}\text { Young } \\
\text { Modulus [GPa] }\end{array}$ & $\mathrm{H} / \mathrm{E}^{*}$ & $\begin{array}{c}\text { Adhesion } \\
{[\mathrm{N}]}\end{array}$ \\
\hline $\mathrm{SS} / \mathrm{Al}_{2} \mathrm{O}_{3}$ & 9.7 & 174.7 & 0.057 & 43.1 \\
\hline $\mathrm{SS} / \mathrm{AlN}$ & 14.3 & 184.4 & 0.078 & 50.3 \\
\hline $\begin{array}{l}\mathrm{SS} / \mathrm{AlN} / \\
\mathrm{Al}_{2} \mathrm{O}_{3}\end{array}$ & 12.9 & 178.6 & 0.071 & 45.9 \\
\hline $\mathrm{Ti} / \mathrm{Al}_{2} \mathrm{O}_{3}$ & 9.2 & 170.3 & 0.052 & 37.1 \\
\hline $\mathrm{Ti} / \mathrm{AlN}$ & 13.8 & 183.1 & 0.075 & 47.2 \\
\hline $\mathrm{Ti} / \mathrm{AlN} / \mathrm{Al}_{2} \mathrm{O}_{3}$ & 12.5 & 177.9 & 0.069 & 40.7 \\
\hline
\end{tabular}

Table 2

Electrochemical parameters of oxide coatings deposited on the stainless steel (1H18N9) and titanium alloy substrates (Ti4Al6V)

\begin{tabular}{|l|c|c|c|}
\hline \multirow{2}{*}{$\begin{array}{c}\text { Material/ } \\
\text { Coating type }\end{array}$} & \multicolumn{3}{|c|}{ Electrochemical parameters } \\
\cline { 2 - 4 } & $\mathrm{E}_{\text {corr }}[\mathrm{V}]$ & $\mathrm{I}_{\text {corr }}[\mathrm{A}]$ & $\mathrm{R}_{\mathrm{p}}[\mathrm{M} \Omega]$ \\
\hline $\mathrm{SS}$ & -0.370 & $8.07 \cdot 10^{-9}$ & 2.7 \\
\hline $\mathrm{SS} / \mathrm{Al}_{2} \mathrm{O}_{3}$ & -0.160 & $2.76 \cdot 10^{-9}$ & 7.9 \\
\hline $\mathrm{Ti}$ & -0.250 & $5.60 \cdot 10^{-9}$ & 3.9 \\
\hline $\mathrm{Ti} / \mathrm{Al}_{2} \mathrm{O}_{3}$ & -0.027 & $5.89 \cdot 10^{-10}$ & 36.9 \\
\hline
\end{tabular}

such as hardness, toughness, elastic recovery and wear resistance of nitride/oxide composite coatings is very important for tribological applications.

The electrochemical parameters of oxide coatings such as corrosion potential (Ecorr), corrosion current density (Icorr) and corrosion resistance (Rp) were evaluated and presented in table 2 .

The oxide coated substrates demonstrate the highest corrosion potential and re-sistance, the lowest corrosion current in comparison with metals both on titanium alloy and stainless steel substrates. The data show that coatings deposition had improved the corrosion resistance parameters by a factor of ten and charge-transfer kinetic perfor-mance of interfaces for both the stainless steel and the titanium alloy substrates.

The contact angles were measured by means of tensiometric method (table 3). Prior to contact angle measurements, samples were ultrasonically cleaned in acetone and deionised water and dried. The standard liquids with well-known values of surface tension, component of dispersion and polar interaction such as water, formamide, diiodo methane, ethylene glycol, $\alpha$-bromo naphthalene and were used.

The average values of the advancing contact angle at $20^{\circ} \mathrm{C}$ temperature

\begin{tabular}{|l|c|c|c|c|c|}
\hline $\begin{array}{c}\text { Substrate/ } \\
\text { coating }\end{array}$ & $\begin{array}{c}\text { Water, } \\
{\left[{ }^{\circ}\right.}\end{array}$ & $\begin{array}{c}\text { Formamide, } \\
{\left[{ }^{\circ}\right]}\end{array}$ & $\begin{array}{c}\text { Ethylene } \\
\text { Glycole, }\left[{ }^{\circ}\right]\end{array}$ & $\begin{array}{c}\text { Diio- } \\
\text { dometane, }\left[{ }^{\circ}\right]\end{array}$ & $\begin{array}{c}\alpha \text {-bromo- } \\
\left.\text { naphthalen, }{ }^{\circ}\right]\end{array}$ \\
\hline $\left.\mathrm{Steel}{ }^{\mathrm{SS}}\right) / \mathrm{Al}_{2} \mathrm{O}_{3}$ & 54.70 & 48.15 & 42.29 & 44.02 & 26.97 \\
\hline $\mathrm{Ti}_{6} \mathrm{Al}_{4} \mathrm{~V}_{\mathrm{Al}} \mathrm{Al}_{2} \mathrm{O}_{3}$ & 55.60 & 44.00 & 44.77 & 46.17 & 28.04 \\
\hline $\mathrm{Steel}(\mathrm{SS})$ & 72.40 & 45.60 & 51.80 & 37.30 & 18.30 \\
\hline
\end{tabular}




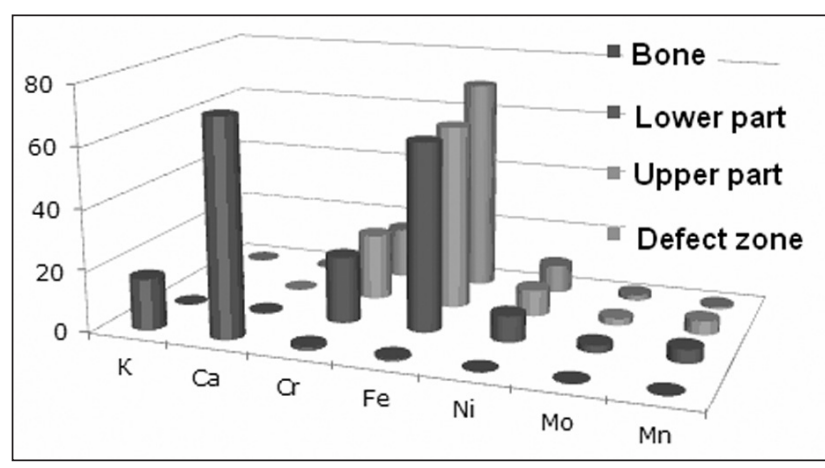

Fig. 2. Changes in chemical composition of the surface of the prosthesis head made of stainless steel, depending on the wear by spectrometry

The results of tensiometric tests show the hydrophilic nature of coated surfaces in comparison with metal one.

Spectral analysis of prosthesis head surfaces made of stainless steel by spec-trometer ElvaX (fig. 2) was made. The change in the ratio of metals in the wear area of the upper pole of the prosthesis head was observed. Marked reduction ratio of iron ions to $1 \%$, molybdenum to $8.3 \%$, without significant changes in the ratio of nickel, chro-mium and manganese contents was detected. In the case of corrosion and surface de-fect's formation, the decrease of ratio of chromium, molybdenum and manganese was detected. In the bone adjacent to the neck of the prosthesis, the presence of chromium ions to $1.1 \%$, and iron to $0.8 \%$ was observed. In the bone cement near the neck of the prosthesis and near the bone the presence of chromium up to $2 \%$, iron up to $1.6 \%$ was detected. Significant differences in the presence of metal ions between the place of fret-ting and bone were not found.

Changes on the surface of titanium heads are more pronounced in areas of wear (fig. 3). The proportion of titanium ions reduced to $1.4 \%$, molybdenum, vana-

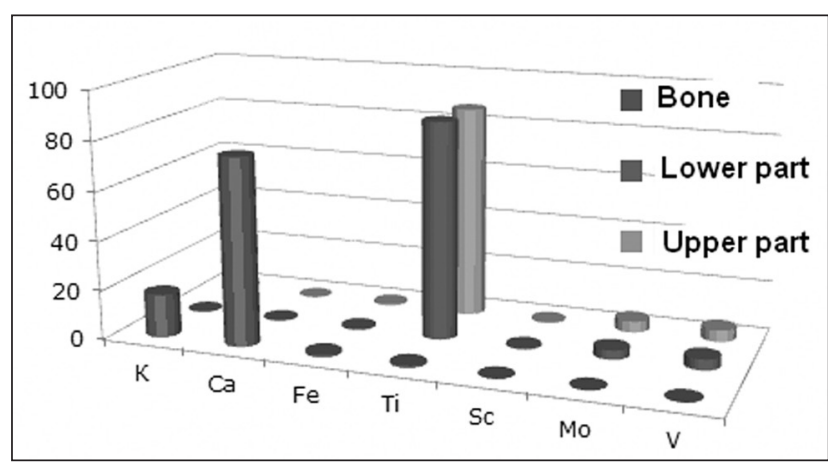

Fig. 3. Changes in chemical composition of the surface of the prosthesis head made of titanium, depending on the wear by spectrometry

dium, iron, scandium proportion remained unchanged. The ratio of calcium and potassium ions in wear area is increased by three times indicated the chemical activity in the wear and corrosion areas. The presence of titanium ions up to $0.8 \%$ in the bone adjacent to the neck of the prosthesis and bone cement was indicated. The obtained results confirm that the active electrochemical processes took place not only in the friction area of metal, metal and bone cement (fretting), but also in the areas of metal friction with cartilage or bone.

In 14 patients with oxide-coated head of prosthesis, observation was carried out for 2-2.5 years with positive results. An example of the use of prostheses with coated heads well illustrated by a clinical case of a patient P. with the right side prosthesis with oxide coated head of conchoid form.

\section{Clinical case}

Patient P., 74 years old. December 20, 2012 year had neck fracture of right hip. 28 December 2012 after the fracture of the right femur head the hemiarthroplastic hip replacement by prosthesis head coated with nanocomposite oxinitride film was made. On the radiograph (fig. 4, a), of the right joint from December 28, 2012
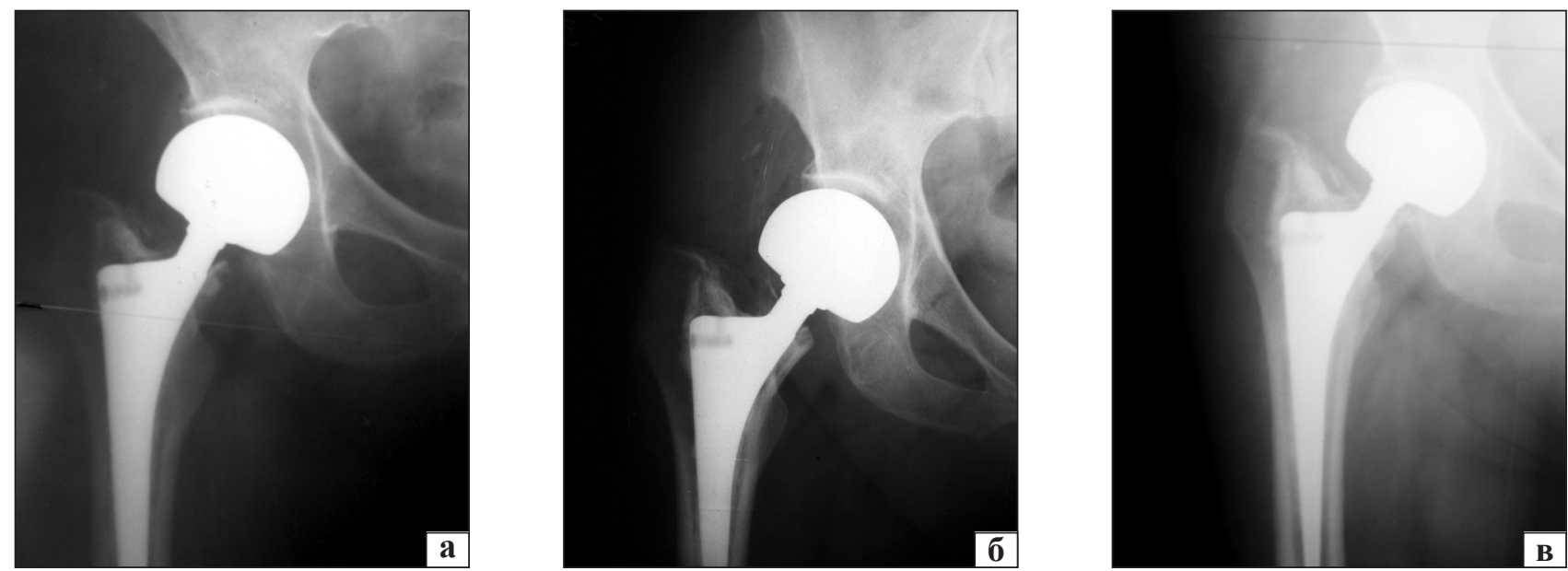

Fig. 4. Radiographs of clinic application of unipolar prosthesis with femoral head coated by nanocomposite oxinitride film 
between head prosthesis and an acetabular gap of $3 \mathrm{~mm}$ was detected. On the radiograph fig. 4, b, of the right hip joint from December 28, 2013 (one year after surgery) between the head of joint and the acetabular gap of 3 $\mathrm{mm}$ and no ossification of the capsule was observed On the radiographs fig. 4, c, of the right hip joint from October 22, 2014 (2 years after surgery) gap of $3 \mathrm{~mm}$ between the head and the acetabular prosthesis and no ossification of the capsule was recorded.

\section{Conclusions}

The nanocomposite ceramic coating deposition on metal femoral head (stainless steel 1H18N9, titanium Ti6Al4V alloys) allows to combine the inertness of ceramic ma-terials with hardness and failure strength of metals, to reduce wear and corrosion of arti-ficial joints and the to advance mechanical parameters of unipolar prosthesis for patients of elder age groups with a femoral neck fractures, as possible applications of this tech-nology.

Titanium head unipolar hip replacements are unstable to mechanical loading. In place of the maximal loads «metal-cartilage», «metal-bone» is an active transfer of the metal ions into the surrounding tissues.

Steel head in hip endoprosthesis are more stable to wear under mechanical fric-tion, but they are unstable to chemical changes and prevention of active metal ions mi-gration into the surrounding tissue, particularly in cases of surface defects formation.

In the process of unipolar prostheses made of titanium and stainless steel produc-ing, the rubbing surfaces of the femoral head require a protective coating of bioinert layer, which should improve safety and tribological properties of friction surfaces.

Ceramic oxide and oxinitride nanocomposite coatings have hydroplilic and bioin-ert properties, which allow protecting the patient from migration of metal ions of the head and improving the tribological performance of the prosthesis. This technical de-velopment is possible to use a bipolar hip prosthesis, as one of the possible applications of this technology.

\section{References}

1. Tribology and total hip joint replacement: Current concepts in mechanical simulation / S. Affatato, M. Spinelli, M. Zavalloni [ et al.] // Med. Eng. Phys. — 2008. — Vol. 30 - P. 1305-1317, doi: 10.1016/j.medengphy.2008.07.006.

2. Varley J. Stability of hip arthroplasties / J. Varley, M. J. Parker // Int. Orthop. - 2004. - Vol. 28 (5). - P. 274-277.

3. Bohm E. R. Employment status and personal characteristics in patients awaiting hip-replacement surgery / E. R. Bohm // Can. J. Surg. - 2009. - Vol. 52 (2). - P. 142-146.

4. Operative management of displaced femoral neck fractures in elderly patients. An international survey / M. Bhandary, P. J. Devereaux, P. Tometta, [et al.] // J. Bone Joint Surg. Am. 2005. - Vol. 87 (9). - P. 2122-2130.
5. Comparison of internal fixation with total hip replacement for displaced femoral neck fractures / R. Blomfeldt, H. Tornkvist, S. Ponzer [et al.] // J. Bone Joint Surg. Am. — 2004. Vol. 87 (8). - P. 1680-1688.

6. Unipolar or bipolar prosthesis for displaced intracapsular hip fracture in octegrnarians a randomized prospective study / S. J. Calder, G. H. Anderson, C. Jagger [et al.] // J. Bone Joint Surg. Br. - 1996. - Vol. 78 (3). - P. 391-394.

7. Internal fixation for displaced fractures of the femoral neck. Does bone density affect clinical outcome? / M. J. Heetveld, E. L. Raaymakers, B. L. van Eck-Smit, J. S. K. Luitse // J. Bone Joint Surg. Br. - 2005. - Vol. 87 (3). - P. 367-373.

8. Loo W. L. Is there a significant difference in surgery and outcomes between unipolar and bipolar hip hemiarthroplasty? A Retrospective study of a single institution in Singapore / W. L. Loo, S. Y. Loh, H. C. Lee // Malaysian Orthopaedic Journal. 2011. - Vol. 5 (1). - P. 3-7, doi: 10.57704/MOJ.1103.001.

9. Unipolar versus bipolar hemiarthroplasty: functional outcome after femoral neck fracture at a minimum of thirty six months of follow up / B. C. Ong, S. G. Maurer, G. B. Aharonoff [et al.] // J. Orthop. Trauma. - 2002. - Vol. 16 (5) - P. 317-322.

10. Unipolar or bipolar hemiarthroplasty for femoral neck fractures in the elderly? / F. J. Raia, C. B. Chapman, M. F. Herrera [et al.] // Clin. Orthop. Relat. Res. - 2003. - Vol. 414 - P. 259-265.

11. Histological features of pseudotumor-like tissues from metalon-metal hips / P. Campbell, E. Ebramzadeh, S. Nelson // Clinic. Orthop. - 2010. — Vol. 468 (9) - P. 2321-2327, doi: 10.1007/s11999-010-1372-y.

12. Comparison of the cytotoxicity of clinically relevant cobaltchromium and alumina ceramic wear particles in vitro / M. A. Germain, A. Hatton, S. Williams [et al.] // Biomaterials 2003. - Vol. 24 (3). - P. 469-479.

13. Ceramic acetabular linear fracture in total hip arthroplasty with a ceramic sandwich cup / M. Hasegawa, A. Sudo, H. Hirata, A. Uchida // J. Arthroplasty. — 2003. — Vol. 18 (5). P. 658-661.

14. Long-term results of total hip arthroplasty for femoral neck fracture nonunion / T. M. Mabry, B. Prpa, G. J. Haidukevych [et al.] // J. Bone Joint Surg. Am. — 2004. — Vol. 86-A(10). P. 2263-2267.

15. The influence of design, materials and kinematics on the in vitro wear of total knee replacements / H. M. J. McEwen, P. I. Barnett, C. J. Bell [et al.] // J. Biomech. - 2005. Vol. 38 (2). - P. 357-365.

16. Treatment of displaced femoral neck fracture, as reflected in Acta Orthopaedica Scandinavica / R. Onnerfalt // Acta Orthop Scand. - 2010. - Vol. 81 (1). - P. 15-20, doi: $10.3109 / 17453671003635801$.

17. Bhatt H. Implant wear mechanisms - basic approach / H. Bhatt, T. Goswami // Biomed. Mater. - 2008. - Vol. 3 (4). Article 042001, doi: 10.1088/1748-6041/3/4/042001.

18. Friction of total hip replacements with different bearings and loading conditions / C. Brockett, S. Williams, Z. Jin [et al.] // J. Biomed. Mater. Res. B Appl. Biomater. - 2007. Vol. 81B. - P. 508-515.

19. Examination of surface and material properties of nano structural oxide coatings for joint total and module replacement arthroplasty / A. Zykova, V. Safonov, J. Smolik [et al.] // Orthopaedics, Traumatology and Prosthetics. - 2013. № 2 (591). - P. 51-57, doi: http://dx.doi.org/10.15674/003059872013251-57.

20. The improvement of tribological parameters of nano structural mulyilayer coatings for unipolar modular joint applications / A. Zykova, V. Safonov, V. Lukyanchenko [et al.] // Orthopaedics, Traumatology and Prosthetics. - 2014. № 1 (594). - P. 28-33, doi: http://dx.doi.org/10.15674/003059872014128-33.

21. Modification of implant material surface properties by means 
of oxide nanostructructural coating deposition / V. Safonov, A. Zykova, J. Smolik [et al.] // J. Appl. Surf. Sci. — 2014. Vol. 310. - P. 174-179, doi: http://dx.doi.org/10.1016/j. apsusc.2014.04.110.

22. Leyland A. Design criteria for wear resistant nano structured and glassy-metal coatings / A. Leyland, A. Mathews // Surf. Coat Technol. - 2004. - Vol. 177-178. - P. 317-321.

23. Musil J. Two-phase single layer Al-O-N nanocomposite films with enhanced resistance to cracking / J. Musil, R. Jilek, M. Meissner [et al.] // Surf. Coat. Technol. - 2012 Vol. 206 (19-20) - P. 4230-4234.

24. Formation of modern bearing surfaces by ceramic coating deposition for micro-bearing and biomedical applications $/$ N. Donkov, A. Zykova, V. Safonov [et al.] // Romanian Reports in Physics. - 2014. - Vol. 66 (4). - P. 1180-1188.

25. Tribological performance of ceramic coatings deposited on metal surfaces for micro-bearing and biomedical applications / V. Safonov, A. Zykova, N. Donkov [et al.] // J. Phys. Conf. Series. - 2014. — Vol. 514. - Article 012017, doi: 10.1088/1742-6596/514/1/012016.

26. Kusano Y. Methods of data analysis for the micro-scale abrasion test on coated substrates / Y. Kusano, K. van Acker, I. M. Hutchings // Surf. Coat. Technol. — 2004. - Vol. 183 (2-3). P. 312-327, doi: 10.1016/j.surfcoat.2003.10.010.

27. Cozza R. C. A study on friction coefficient and wear coefficient of coated systems submitted to micro-scale abrasion tests / R. C. Cozza // Surf. Coat. Technol. — 2013 - Vol. 215 P. 224-233, doi: 10.1016/j.surfcoat.2012.06.088.

Article submitted on 08.12.2014

\section{УНИПОЛЯРНЫЕ ЭНДОПРОТЕЗЫ ТАЗОБЕДРЕННОГО СУСТАВА С ГОЛОВКОЙ, ПОКРЫТОЙ НАНОКОМПОЗИТНОЙ КЕРАМИКОЙ}

А. Зыкова ${ }^{1}$, В. Сафонов ${ }^{1}$, В. Лукьянченко ${ }^{2}$, А. Самойленко ${ }^{3}$, Р. Роговска ${ }^{4}$, Дж. Смолик ${ }^{4}$, Н. Донков ${ }^{5}$

${ }^{1}$ Национальный научный центр «Харьковский физико-технический институт». Украина

${ }^{2}$ Инмайстерс Лтд, Харьков. Украина

3 Луганский государственный медицинский университет. Украина

${ }^{4}$ Институт теротехнологии, Радом. Польша

${ }^{5}$ Институт электроники Болгарской академии наук, София. Болгария

\section{ДО УВАГИ СПЕЦІАЛІСТІВ}

ДУ «Інститут патології хребта та суглобів ім. проф. М. І. Ситенка НАМН України» проводить післядипломну підготовку фахівців на курсах інформації та стажування з актуальних питань ортопедії та травматології (ліщензія Міністерства освіти і науки України АЕ № 285527 від 27.11.2013)

\section{Курси для середнього медичного персоналу:}

№

1. Функціональні та фізіотерапевтичні методи лікування хворих з ортопедо-травматологічною патологією

2. Гіпсово-ортопедична техніка та лікування хворих з ортопедо-травматологічною патологією

3. Лікувальний масаж
Керівники

Проф. Маколінець В. I. К.м.н. Стауде В. А. Д.м.н. Мателенок $€$. М. Д.м.н. Мезенцев А. О. К.м.н. Стауде В. А. 